\title{
OFFER AND ACCEPTANCE IN CONTRACTS BY CORRESPONDENCE*
}

WHEN contracting parties deal with one another by mail or telegram, courts almost uniformly consider the deposit of an "acceptance" with the transmitting agency as the moment of contract birth. ${ }^{1}$ While operation of this "deposited acceptance" rule is said to be conditioned upon an express or implied authorization by the offeror of the offeree's use of the specific transmission service, ${ }^{2}$ this condition is rarely found absent. Judicial construction traditionally has made a mailed or telegraphed offer an implied invitation to accept by the same medium of communication. ${ }^{3}$

Since first established in the famous King's Bench case of Adams v. Lindsell, ${ }^{4}$ the deposited acceptance rule has been applied by the courts of England and the United States with strict regard for stare decisis. ${ }^{5}$ In Dick v. Unitcd

* Dick v. United States, 82 F. Supp. 326 (Ct. Cl. 1949).

1. 1 Wirliston, Contracts $\$ 81$ n.2, 3, 4 (rev. ed. 1936); Restatearent, Contracts $\S 64$ (1932).

2. 1 Williston, Contracts $\$ 83$ n.1, 2, 3, 4; Restatenent, Contracts $\$ 64$.

3. 1 Williston, Contracts $\$ 83$ n.1, 2, 3, 4; Restatement, Contracts $\$ 66$. Acceptance by a medium of communication neither expressly nor impliedly authorized by the offeror moves the moment of contract birth up to the delivery of the acceptance to the offeror. Thus, an offeror may revoke his offer, and an offeree may withdraw or revoko his acceptance, at any time prior to such delivery. Accordingly, if such an "unauthorized" acceptance becomes lost en route to the offeror, or if such an acceptance becomes delayed beyond that reasonable period in which the offer is "open," no contract will be formed. While it may under most circumstances be fair to assume that a mailed acceptance will be too late to bind one whose offer was sent by telegram, it is difficult to understand why a telegraphed acceptance should not be proper where the offer was mailed. If the deposited acceptance rule is practical in a given fact situation, its application should not turn upon "authorization," but rather, on the convenience of the contracting partics. In order to avoid the difficulties that might arise under an overly technical application of the "authorization" doctrine, the draftsmen of the new Commercial Code have rejected the doctrine entirely, and substituted in its place the proposal that any medium of communication may be permissible if "reasonable in the circumstances." Untrorar Coasartrcial Code §2-206 (1) (a) (May Draft, 1949).

4. 1 B. \& Ald. 681, 106 Eng. Rep. 250 (K.B. 1818).

5. See cases cited, 1 Wilurston, Contracts $\$ 81$ n.4. McCulloch v. Eagle Ins. Co., 1 Pick. 277 (Mass. 1882) (offer to insure held revocable until acceptance reaches offeror), is the only reported English or American decision in which the contract was held to bo binding only when the acceptance reached the offeror. Although never explicitly overruled, its future application in Massachusetts seems doubtful. See Brauer v. Shaw, 168 Mass. $198,200,46$ N.E. 617, 618 (1897) (offer to let space on cargo ship held not revocable after dispatch of telegraphed acceptance). But cf. Traders' Nat. Bank v. First Nat. Bank, 142 Tenn. 229, 217 S.W. 977 (1920) (drawee bank's acceptance of check held voidable by withdrawal of letter containing acceptance from mails); Guardian Nat. Bank v. Huntington County State Bank, 206 Ind. 185, 187 N.E. 388 (1933) (acceptance or payment of check held not irrevocable where drawee bank withdrew from mails credit letter before it reached collecting bank). 
States, ${ }^{6}$ however, the Court of Claims refused to follow this long chain of precedent.

After executing and mailing an acceptance of a government propeller purchase order, plaintiff manufacturer, sole bidder on the contract, discovered that he had erroneously understood the agreement as calling for only one-half the parts actually required. He immediately wired the government purchasing officer that the purchase price should be doubled, and this notice reached the government officer before the previously mailed acceptance. Reformation negotiations were then commenced and, apparently confident of their successful outcome, plaintiff manufactured and delivered the entire quantity of parts. When the reformation negotiations failed, action was brought by plaintiff to recover the fair value of the additional parts. Demurring to the complaint, the government alleged that it had received no notice of the mistake until after a binding contract had been formed by the plaintiff's mailing of the accepted purchase order. The demurrer was overruled.

To get this result, the Court of Claims felt that it was faced with the choice of either overruling the venerable doctrine that unilateral mistalie is irrelevant, ${ }^{8}$ or refusing to apply the equally venerable deposited acceptance rule. It took the latter course. The court based its opinion upon United States Postal Regulations which permit the sender of deposited mail to recover it at any time prior to its actual delivery to the addressee. ${ }^{9}$ Stating the traditional view that the deposited acceptance rule rests on the theory that an offeree abandons physical control of his acceptance by depositing it in the mail, ${ }^{10}$ the court sug-

6. 82 F. Supp. 326 (Ct. Cl. 1949).

7. Brief for Defendant filed in argument on demurrer, p. 13. See discussion of mistake doctrine, note 8 infra.

8. Ordinarily, for a party to obtain relief under mistake doctrines, it must be shown that the mistake was mutual or so palpable that the other party must have lnown of it. Both possibilities would have been difficult to show in the principal case. The government did not have actual prior notice before the acceptance was mailed. Nor did it have experience in previous purchases of this sort so as to be able to judge the palpable nature of plaintiff's mistake. For discussion of the mistake doctrine see 1 Wnurston, Co:irnscts \$94; 5 Wintiston, Contracts \$1578; Lubell, Unilateral Palpable and Impalfable Mistake in Construction Contracts, 16 MrNs. L. Rev. 137 (1932); Patterson, Egutable Relief for Unilateral Mistake, 28 CoL. L. REv. 859 (1928). For views urging liberalization of the doctrines of unilateral mistake, see Sharp, Williston on Contracts, $4 \mathrm{U}$. of Cur. L. REv. 30, 31-9 (1936) ; Judge Frank's concurring opinion in Ricketts v. Pennsylvania RR, 153 F.2d 757, 760 (2d Cir. 1946) ; Note 5, U. of CEI. L. REv. 446 (1938).

9. 39 CODE FED. REGS. \$ \$ 10.9, 10.10, 16.17 (1938).

10. 82 F. Supp. 326,329 (1949). Although the more common explanation of the deposited acceptance rule is cast in agency terminology, this is esschtially a control theory. In agency language, the depositing of the acceptance with the transmitting service is deemed to be a handing over of the acceptance to the agent of the offeror. See cases cited, 1 WuLtiston, Contracts $\$ 81$ n.4. Whether the deposited acceptance rule is cast in terms of agency or control, the underlying thought is that the depositing of the acceptance makes it irretrievable by the offeree. Of course, even if the depositing were to mean that the offeree could not recover his acceptance-which it does not-it would not necessarily follow that the contract should become binding at that moment. The courts 
gested that the rule should not be applied where, as here, the Postal Regulations permit its recovery. ${ }^{11}$ In propounding this truly remarkable theory, the court in effect nullified the deposited acceptance rule completely, since under existing regulations all letters can be recovered, and wires may also be stopped if intercepted in time by a subsequent telegram. ${ }^{12}$

What purports to be a more practical approach to the problem of offer and acceptance by correspondence is offered by commentators who urge retention of the deposited acceptance rule solely for its utilitarian value as a "businessman's rule". ${ }^{13}$ The argument is that if the contract were not considered binding until the acceptance reached the offeror, an offeree could not go ahead on the deal before that time without risking the arrival of a revocation from the offeror. Such a revocation would be effective under standard contract doctrine that a promise unsupported by consideration is not binding. ${ }^{14}$

Doubtless, immediate offeree-reliance is vital in some businesses-especially those concerned with rapid purchase and resale transactions. ${ }^{15}$ But there is some evidence which indicates that not all businessmen regard the deposited acceptance rule favorably. A recent study of the contract practices of ten leading Connecticut business concerns in varying industries shows that a number of businessmen not only dislike the rule generally, but also fear that its application to their own business would reward "unfair" business practice. Of the ten concerns interviewed, only one admitted unqualified approval of the rule. ${ }^{10}$ Some had never heard of it. Unfortunately, the survey was of

might have, had they wished, picked any point in the negotiations as the moment of contract birth.

11. 82 F. Supp. 326,329 (1949). As an alternative rationale for its decision, the court could have stated that the government, by carrying on reformation negotiations, was estopped from claiming "acceptance."

12. Communication to the YaIe Law Journal from H. C. Crutchfield, Superintendent, Western Union Telegraph Co., New Haven, Conn., dated Nov. 18, 1949, in Yale Law Library.

13. Corbin, Cases on Contracts 72-3 (3d ed. 1947); Llewellyn, Our Case Law of Contract: Offer and Acceptance, 48 Yale L.J. 779, 795 (1939); Winfield, Some Aspects of Offer and Acceptance, 55 L.Q. REv. 499, 505-15 (1939); 34 CORNELL. L. Q. 632 (1949) (principal case discussed); 62 HARv. L. REv. 1231 (1949) (principal case discussed); 35 VA. L. Rev. 508 (1949) (principal case discussed). But see Langdell, Summary of TIIE Law of Contracts 15-21 (2d ed. 1880); Nussbaum, Comparative Aspects of the AngloAmerican Offer-and-Acceptance Doctrine, 36 Coz. L. REv. 920 (1936).

14. Dickinson v. Dodds, 2 Ch. D. 463 (C.A. 1876). 1 Williston, Contracts $\$ 55$; REsTatenrent, Contracts $\$ \$ 34,35$.

15. The likelihood is that most transactions of this sort can and will be carricd out by telephone. Of course, where telephonic communication is available and practicable, the deposited acceptance rule is of no importance.

16. Of the ten business concerns in Connecticut interviewed by questionnaire, eight stated that they considered a contract binding only when the acceptance reaches the offeror; five stated that they had never heard of the deposited acceptance rule; nine felt that the rule's application without regard for their own business practices and understandings might adversely affect their businesses and possibly reward unfair business practice. Completed questionnaires in Yale Law Library. 
too limited a scope to warrant final conclusions either one way or the otherif indeed final conclusions are obtainable. But the results make it doubtful that the rule may aptly be called a businessman's rule.

This doubt is strengthened in the fact situation of the Dick case. Since there were no other bidders on the contract, ${ }^{17}$ and since the notice of plaintiff's mistake reached the government purchasing officer before the previously mailed acceptance, ${ }^{18}$ it is difficult to see what real harm the government could suffer by paying the fair price for the parts. Had the deposited acceptance rule been applied, the government would have received a windfall of free propeller parts, and the manufacturer would have lost the benefit of a fair bargain.

Since common understanding on the tying or untying of a contract apparently varies from market to market, the moral of the Dick case may well be that blanket rules are to be avoided. There is always a danger that an unimaginative court may deprive someone of a profit which business custom and usage would say he had made. ${ }^{19}$

17. 82 F. Supp. 326, 327 (1949).

18. Id. at 328 .

19. If custom or trade usage were offered into evidence in order to void a contract that the law would otherwise regard as binding under the deposited acceptance rule, it is possible that some courts would refuse to admit it. Thus far, courts have exhibited a reluctance to permit the introduction of trade usages and previous dealings for any purpose other than interpretation of a contract. The general notion seems to be that custom and usage may neither create nor void a contract. See, e.g., Stulsaft v. Mfercer Tube \& Affg. Co., 288 N.Y. 255, 43 N.E.2d 31 (1942); Hagedorn \& Co. v. Godwin \& Strauss, 142 Pa. Super. 547, 16 A.2d 649 (1940).

An exception to the general rule that usage and custom may not create a contract is made where evidence of previous dealings is offered to show that silence is intended to mean assent. T. C. May Co. v. Menzies Shoe Co., 184 N.C. 150, 113 S.E. 593 (1922) (custom may be shown to indicate that silence meant acceptance of order for shoes); Cole-MicIntyre-Norfleet Co. v. Holloway, 141 Tenn. 679, 214 S.W. 817 (1919) (previous dealings may be introduced to show that silence is intended to mean assent) ; 1 WuLIston, Contracts \$9iC; Restatearent, Contracts \$72 (1) (c). The Cole-AicIntyreNorfleet case is criticized, but the exception supported, in Corbin, When Silence Gires Consent, 29 YaLE L.J. 441 (1920). An extension of this exception is possibly suggested by way of dictum in Albert v. Farnsworth, 176 F.2d 198, 201 (5th Cir. 1949), where the court indicated that trade custom could, if shown to be clear and specific, be introduced to replace a principle of law; but the custom offered was not shown to be adequately clear. Moreover the dictum is apparently contradicted by another statement in the opinion that custom may not create a contract.

The new Uniform Commerical Code neither denies nor affirms that previous dealings or trade usages may create or void a contract. Section 1-205 (3) (Mlay Draft, 1949) states: "The parties to a contract are bound by any course of dealing between them and by any usage of trade of which both are or should be aware and parties engaged in a particular vocation or trade are bound by its usages." Under "Purposes of Changes" the draftsmen explain section 1-205: "(4) This Act deals with 'usage of trade' as a factor in reaching the commercial meaning of the agreement whicls the fartics haze made." (Emphasis added). Query: Is it to be inferred from this explanation that the function of trade usage is to be limited to that of interpretation?

It is difficult to ascertain why there is this general hesitation to permit usage and 
But it can probably be said with great confidence that most courts are ingenious enough to circumvent blanket rules where justice so demands.20 Hence if it should be desirable as a limit to litigation to select an arbitrary point at which a contract is formed, might not the court's holding in this case be turned into a blanket validation of all revocations which overtake deposited acceptances ? $^{21}$ It is difficult to see how any gross injustice could result. The offeror can always specify the manner and speed of acceptance, if they are important to him. ${ }^{22}$ Moreover, permitting revocation would not in any way increase the offeror's risks, since he cannot begin to rely before he hears from the offeree. ${ }^{23}$ Should the opportunity to make a bargain elsewhere arise while he is still unaware of the offeree's actions, he has merely to pick tup a telephone to find out. Indeed, given modern methods of quick communication, perhaps the only function performed by an acceptance or revocation rule is to determine which party has the burden of checking on the status of their negotiations.

Thomas F. Bergint

custom to create or void a contract. In all probability the fear is that situations might arise where parties would be bound by practices of which they had no knowledge. But where the custom or usage offered is so notorious as to be common knowledge within a trade, it would seem unduly cautious for a court to limit its tise to mere interpretation. There are times when custom is as meaningful as words. That courts have recognized this is indicated by the frequent judicial use of a term like "implicd-in-fact contracts." What but custom is the operative "fact" from which the contract is "implied"? 1 Wiltuston, Contracts \$3; Costigan, Implied-in-Fact Contracts and Mutual Asscut, 33 Hanv. L. Rev. 376 (1920); Whittier, The Restatement of Contracts and Muttul Assemt, 17 CALIF. L. Rev. 441, 449-51 (1929).

20. In many instances, for example, it is very easy to say that an "acceptance" was not an acceptance at all, but rather an "offer."

21. See Indian Contract Acr $\$ \S 4,5$ (Pollock ed. 1905). For a modified version of this proposal, and a more traditional approach to this vital legal problem, see 62 Hunv. L. Rev. 1231, 1232 (1949). See also Restatenrent, Contracts $\$ 39$ (1932), which validates an acceptance that overtakes a rejection.

22. See note 2 supra.

23. See note 21 sitpra.

$\dagger$ Member of the second-year class, Yale Law School. 